\title{
ESTIMATION OF STATURE OF INDIVIDUAL WITH THE HELP OF
} LENGTH OF ULNA

\section{Anuj Jain1, Ashok Kumar*2.}

${ }^{1}$ Professor, Department of Anatomy, U.P. University of Medical Sciences, Saifai, Uttar Pradesh, India.

${ }^{* 2}$ Junior Resident, Department of Anatomy, U.P. University of Medical Sciences, Saifai, Uttar Pradesh, India.

\section{ABSTRACT}

Introduction: Stature is the natural height and built of a body or person. Stature has been one of the most important factor in the description of the human body characteristics. Various types of parameters are used while estimating stature of human body. Prediction of stature with the help of length of ulna appears to be significant to forensic Science experts, anthropologists, archeologists and demographers.

Aim: The aim of the study was to establish a relationship between the stature of an individual and the length of ulna.

Materials and Methods: This study was conducted on 240 medical, paramedical students and staff in age group of 20-50 of UP University of Medical Sciences, Saifai, Etawah, UP, India. Length of ulna of subjects was measured by Vernier caliper in similar anatomical position and at fixed time to avoid diurnal variation. Correlation and Regression analysis were carried out to establish relationship of length of ulna with the height.

Results: Statistical significant positive correlations between length of right ulna and the height for male ( $r=0.6784$; $p$-value $<0.00001)$ and for female $(r=0.6617$; $p$-value $<0.00001)$, and between length of left ulna and the height for male $(r=0.6828 ; p$-value $<0.00001)$ and for female $(r=0.6275 ; p$-value $<0.00001)$ were observed respectively. Regression equations for stature were also derived.

Conclusion: The finding of study suggest that length of both right and left ulna can be successfully used for stature reconstruction.

KEY WORDS: Ulna Length, Stature, Anthropology, Stadiometer.

Address for Correspondence: Dr. Ashok Kumar, S/O Shri Parmeshwar Gupta, Sadar Bazar, Purani Bazar, Sabji Mandi, Lalganj, Raebareli - 229 206, Uttar Pradesh, India. Mob: +919889549325.

E-Mail: kumarashok100382@gmail.com

Access this Article online Quick Response code

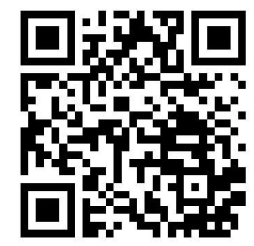

DOI: $10.16965 /$ ijar.2018.440

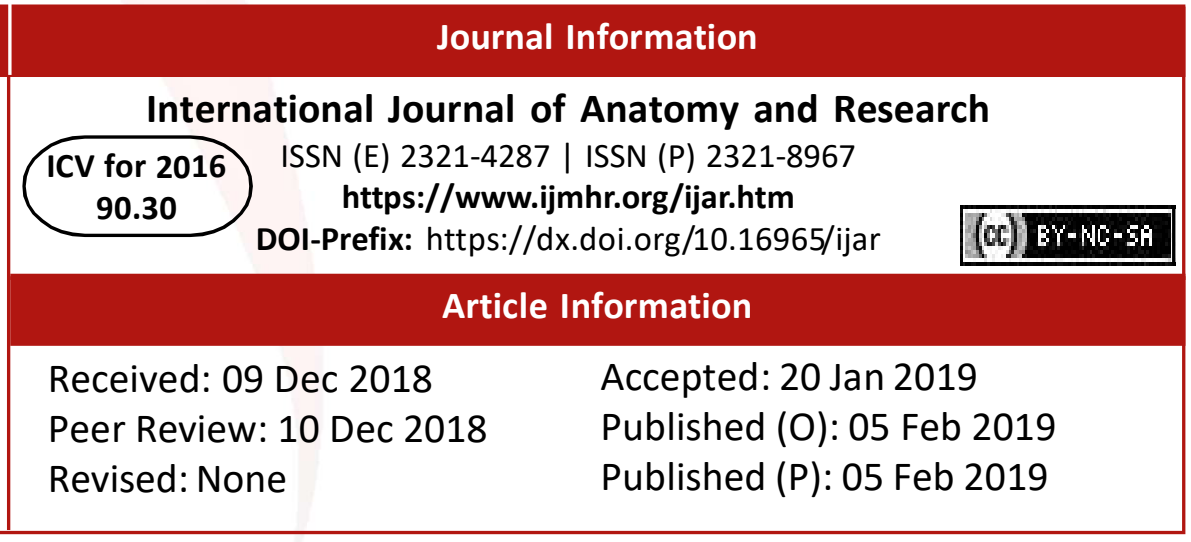

Reconstruction of stature from various bones of

\section{INTRODUCTION}

Stature is an identifying characteristics which provides useful information to solve the crime [1]. The stature prediction occupies relatively a central position in the identification, necessitated by the medico-legal experts or medical jurisprudence and anthropological research [2]. the human skeleton has been achieved by many scientists with varying degree of accuracy [3]. The use of anthropometry in the field of forensic science \& medicine dates back to 1882 , when a French police (Alphonse Bertillon) expert invented a system of criminal identification based 
on anthropometric measurements. His system was based on three fundamental ideas- the fixed condition of the bone system from the age of twenty till death, the extreme diversity of dimensions present in the skeleton of one individual compared to those in other, the ease $\&$ relative precision with which certain dimension of the bone structure of a living person can measured using simply constructed callipers [4].

At the age of peak growth velocity, the upper limbs are more developed than the lower limbs, and the distal segments, such as the tibia, fibula and forearm, precede the proximal segments [5]. Thus, along with genetics, nutritional and/or disease stresses at a particular developmental and growth stage would affect the various biological systems differently, resulting in limb proportion variation among populations.

All methods of stature estimation are based upon the fundamental assumption that the longer the bone, the taller the individual $[6,7]$. There are two classes of stature estimation methods: anatomical and mathematical[6]; each has advantages and disadvantages. Anatomical methods measure the entire length of the body and incorporate adjustments for factors present or absent after death. [8,9] Mathematical methods, including linear regression [8,7], use the relationship between the size of a bone or combination of bones and the height of the individual, over large samples, to create a formula to estimate stature on unidentified remains.

Ulna bone as it is subcutaneous and hence surface landmarks such as olecranon and styloid process are easily identifiable and can be used for measurements [10]. A large number of studies have been done on stature estimation using the length of bones such as femur, tibia, humerus, radius, height from finger length etc. The purpose of this study is to estimate that which parameter is better for stature estimation, from length of right ulna or length of left ulna.

\section{MATERIALS AND METHODS}

This study was conducted in the Department of Anatomy, Uttar Pradesh University of Medical Sciences, Saifai, Etawah, Uttar Pradesh, India. Ethical clearance was obtained from the ethical committee of the college prior to the study. This study was a Cross-Sectional study. The study was conducted on 240 medical, paramedical students and staff of age group of 20 to 50 years of age in UPUMS, Saifai, Etawah, UP, India. Any subject having any significant diseases, orthopedic disability and paralysis was excluded from the study. Subjects not giving consent to participate in the study were also excluded from the study.

The researcher obtained the permission from the UPUMS, Saifai. The length of ulna was measured by Vernier Caliper, and height of individual was measured by Stadiometer. Vernier calipers capable of measuring of the nearest $0.02 \mathrm{~mm}$ and Stadiometer capable of measuring nearest $0.1 \mathrm{~cm}$. All data was entered into SPSS Software V.23.0. Data was analyzed and correlation coefficient was also calculated.

Fig.1: Vernier Caliper.

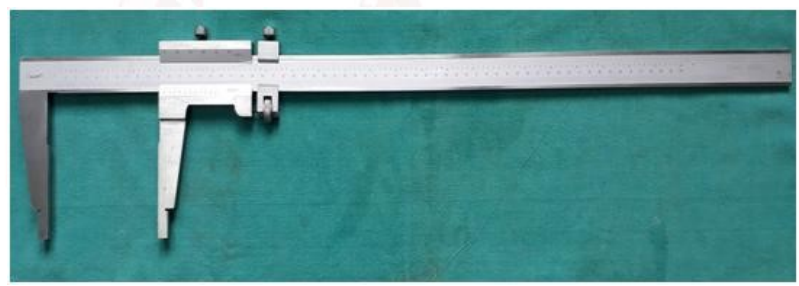

Fig.2: Stadiometer.

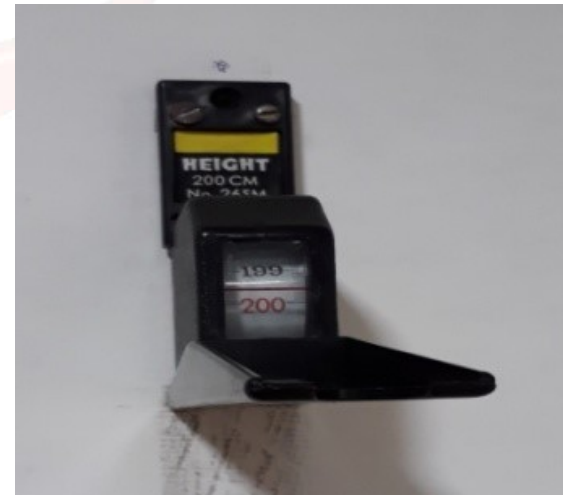

Length of ulna was measured as distance between the tip of the olecranon process and styloid process of ulna while the elbow in state of semi flexion of both sides right and left. Stature was measured as vertical distance from vertex to the floor by making the subject stand erect on a horizontal resisting plane bare footed with shoulder blocks and buttocks touching the wall. Palms of hand had to be turned inwards and fingers horizontally pointing downwards. Anthropometer was placed in straight vertical position in front of the subject with head oriented in eye-ear-eye Plane (Frankfurt- Plane). 
The movable rod of the Anthropometer was brought in contact with vertex in the mid-saggital plane.

Fig.3: Measurement of Length of Ulna.

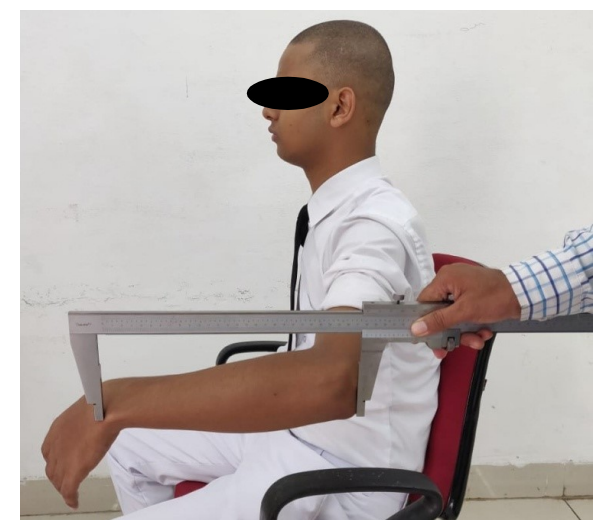

Fig.4: Measurement of Height (Stature).

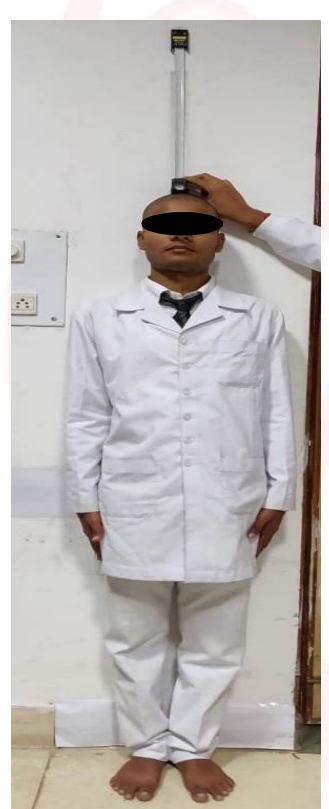

\section{OBSERVATIONS AND RESULTS}

The results from the study show that the mean and standard deviation of height in male subjects was $168 \pm 6.18 \mathrm{~cm}$, and in female subjects was $156.35 \pm 5.99 \mathrm{~cm}$, while the mean and standard deviation of length of right ulna in male was $27.95 \pm 1.43 \mathrm{~cm}$, and in female was $25.33 \pm 1.42 \mathrm{~cm}$., and the mean and standard deviation of length of left ulna in male was $27.68 \pm 1.48 \mathrm{~cm}$. and in female was $25.19 \pm 1.45 \mathrm{~cm}$.

Statistical significant positive correlations between length of right ulna and the height for male $(r=0.6784 ; p$-value $<0.00001)$ and for female $(r=0.6617 ; p$-value $<0.00001)$, and between length of left ulna and the height for male $(r=0.6828 ; p$-value $<0.00001)$ and for female $(r=0.6275 ; p$-value $<0.00001)$ were observed by using Pearson's correlation coefficient respectively. A linear relation was observed between height and length of right ulna in both male and female, and a linear relation was also observed between height and length of left ulna in both male and female.

Table 1: Gender wise measurements and analysis of stature.

\begin{tabular}{|c|c|c|c|c|}
\hline Stature & $\begin{array}{c}\text { Minimum } \\
(\mathrm{cm} .)\end{array}$ & $\begin{array}{c}\text { Maximum } \\
(\mathrm{cm} .)\end{array}$ & $\begin{array}{c}\text { Mean } \\
(\mathrm{cm} .)\end{array}$ & SD $(\mathrm{cm})$. \\
\hline $\begin{array}{c}\text { Male } \\
(\mathrm{n}=155)\end{array}$ & 149.2 & 188.8 & 168.92 & 6.18 \\
\hline $\begin{array}{c}\text { Female } \\
(\mathrm{n}=85)\end{array}$ & 134.9 & 173.8 & 156.35 & 5.99 \\
\hline
\end{tabular}

(SD=Standard deviation)

Table 2: Gender wise measurements and analysis of length of ulna.

\begin{tabular}{|c|c|c|c|c|c|c|}
\hline Ulna Length & $\begin{array}{c}\text { Minimum } \\
(\mathrm{cm} .)\end{array}$ & $\begin{array}{c}\text { Maximum } \\
(\mathrm{cm} .)\end{array}$ & Mean (cm.) & SD (cm.) & $r$ & $p$-value \\
\hline $\begin{array}{c}\text { Right side } \\
\text { (Male) }\end{array}$ & 24.08 & 32.97 & 27.95 & 1.43 & 0.6784 & $<0.00001$ \\
\hline $\begin{array}{c}\text { Right side } \\
\text { (Female) }\end{array}$ & 21.172 & 31.102 & 25.33 & 1.42 & 0.6617 & $<0.00001$ \\
\hline $\begin{array}{c}\text { Left side } \\
\text { (Male) }\end{array}$ & 23.73 & 33.148 & 27.68 & 1.48 & 0.6828 & $<0.00001$ \\
\hline $\begin{array}{c}\text { Left side } \\
\text { (Female) }\end{array}$ & 21.9 & 30.612 & 25.19 & 1.45 & 0.6275 & $<0.00001$ \\
\hline
\end{tabular}

( $r=$ Pearson's correlation coefficient, $p$-value=Probability) Fig. 5: Height in erect position and length of right ulna in male

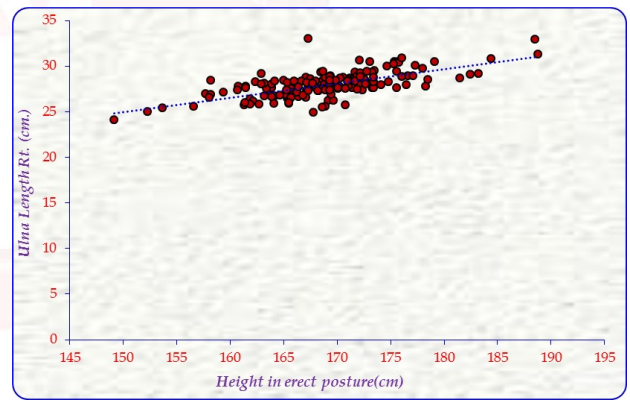

Fig. 6: Height in erect position and length of right ulna in female.



Fig.7: Height in erect position and length of left ulna in male.

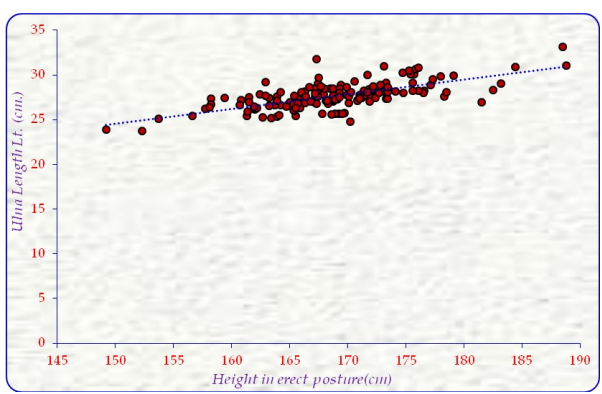


Fig. 8: Height in erect position and length of left ulna in female.

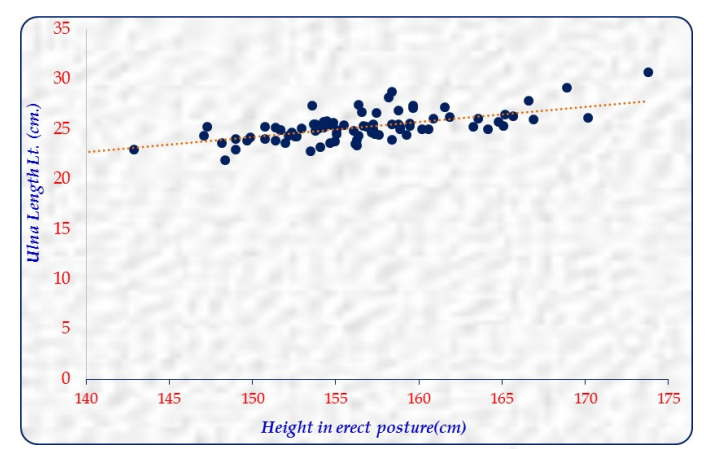

Regression analysis enables us to predict the values of one variable on the basis of other variable. Regression equation for present study was calculated on SPSS Software V.23.0. A simple linear regression formula: $\mathrm{H}=\mathrm{a}+\mathrm{bP}$ was derived, where $\mathrm{H}=$ Height $(\mathrm{cm}$.$) is one variable,$ $a=$ Constant $(\mathrm{cm}),. b=$ Regression coefficient, $\mathrm{P}=$ Length of Ulna $(\mathrm{cm}$.$) is another variable. Re-$ gression equations for stature were derived as follows:

$\mathrm{H}=87.22+2.92 \mathrm{P}$ for length of right ulna of male $\mathrm{H}=85.84+2.78 \mathrm{P}$ for length of right ulna of female $\mathrm{H}=89.98+2.85 \mathrm{P}$ for length of left ulna of male $H=91.04+2.59 P$ for length of left ulna of female

\section{Calculation of Height-}

(1) From length of right ulna in male:

$$
\begin{aligned}
& \mathrm{P}=29.52 \\
& \mathrm{H}=87.22+2.92 \times 29.52 \\
& \text { Calculated Height }=173.50 \mathrm{~cm} . \\
& \text { Measured Height }=173.5 \mathrm{~cm} .
\end{aligned}
$$

(2) From length of right ulna in female:

$$
\begin{aligned}
& \mathrm{P}=26.07 \\
& \mathrm{H}=85.84+2.78 \times 26.07 \\
& \text { Calculated Height }=158.42 \mathrm{~cm} . \\
& \text { Measured Height }=158.4 \mathrm{~cm} .
\end{aligned}
$$

(3) From length of left ulna in male:

$$
\begin{aligned}
& \mathrm{P}=27.8 \\
& \mathrm{H}=89.98+2.85 \times 27.8 \\
& \text { Calculated Height }=169.27 \mathrm{~cm} . \\
& \text { Measured Height }=169.3 \mathrm{~cm} .
\end{aligned}
$$

(4) From length of left ulna in female:

$$
\begin{aligned}
& \mathrm{P}=23.572 \\
& \mathrm{H}=91.04+2.59 \times 23.572 \\
& \text { Calculated Height }=152.16 \mathrm{~cm} . \\
& \text { Measured Height }=152 \mathrm{~cm} .
\end{aligned}
$$

The estimated statures, calculated with the help of regression equations of length of both right and left ulna for male and female are found approximate to their measured values.

\section{DISCUSSION}

Estimation of stature from bones especially longer ones, is preferred because of higher correlation, and thus to identify an unknown individual. The present study provides valuable new data pertaining to the length of ulna and its correlation with the stature in adult Indian population. A general linear regression model was found to be most promising and validating in both male and female.

Correlation between length of right and left ulna with height in male with correlation coefficient (r) of 0.6784 and 0.6828 respectively interpreting that length of right and left ulna may be good tool for estimation of height in male. Pearson's correlation was used to predict the significant relationship between the height and length of ulna of the subjects. This indicates an equally high significant $(P<0.00001)$ relation between length of right ulna and the height, and also that between length of left ulna and the height $(P<0.00001)$ in case of male .

Correlation between right ulna length and left ulna length with height in female with correlation coefficient ( $r$ ) of 0.6617 and 0.6275 respectively interpreting that length of right and left ulna may be good tool for estimation of height in female. Here also an equally high significant $(P<0.00001)$ relation exists between length of right ulna and the height, and also that between length of left ulna and the height $(P<0.00001)$ in case of female.

Correlation coefficient ( $r$ ) of length of ulna with height interprets that length of left ulna can give more accurate measurement than length of right ulna, in case of male, and length of right ulna can give more accurate measurement than length of left ulna, in case of female.

In the study of Anupriya (2016)[11], the correlation coefficient $(r)$ was 0.754 for length of right ulna and 0.745 for length of left ulna in males; 0.691 for length of right ulna and 0.701 for length of left ulna in females. That value of $r$ showed a positive correlation and indicated a very high 
Table 3: Comparison of regression coefficient of our study with other studies in different populations.

\begin{tabular}{|c|c|c|c|c|c|}
\hline \multirow{2}{*}{ Study } & \multirow{2}{*}{ Region } & \multicolumn{2}{|c|}{ Ulna of Male } & \multicolumn{2}{c|}{ Ulna of Female } \\
\cline { 3 - 6 } & Right & Left & Right & Left \\
\hline Present study & $\begin{array}{c}\text { different parts } \\
\text { of India }\end{array}$ & 2.92 & 2.85 & 2.78 & 2.59 \\
\hline Anupriya A et al [11] & Tamil Nadu & 3.631 & 3.551 & 3.745 & 3.839 \\
\hline Illayaperumal et al. [14] & Sri Lanka & 2.645 & 2.645 & 3.536 & 3.536 \\
\hline Allbrook [15] & British & 3.06 & 3.06 & 3.06 & 3.06 \\
\hline
\end{tabular}

significant $(P<0.001)$ relation between the length of the ulna and the height.

This was also similar to Mondal et al (2012)[12] who observed that correlation coefficient $(r)$ was 0.786 for length of right ulna and 0.687 for length of left ulna in males; 0.67 for length of right ulna and 0.82 for length of left ulna in females. This study showed that length of ulna bone could give a correct estimation of height because of a very high significant relation between the length of ulna and height.

According to Lal and Lala [13] regression coefficient (b) is a better guide for calculation of height of an individual when the identity of the individual is not known.

\section{CONCLUSION}

One hundred fifty five adult male and eighty five female subjects have been studied for their stature, length of right ulna and length of left ulna. Statistically high significant correlation is present among the stature and these measurements. This study shows that there is a definitive and good correlation between the height and length of both right and left ulna in both sexes. The regression equations have been derived from these measurements. The regression equation for reconstruction of stature from length of both right and left ulna in both sexes is $\mathrm{H}=\mathrm{a}+\mathrm{bP}$ where, $\mathrm{H}=\mathrm{Height}, \mathrm{a}=$ Constant, $\mathrm{b}=$ Regression Coefficient and $\mathrm{P}=$ Length of Ulna.

India is a country of different races so there is a lot of variation in the estimates. Hence there is a need to conduct more studies among people of different regions \& ethnicity, so that stature estimation becomes more reliable \& identity of an individual is easily established. As this study is done in living individuals so the results may not be applicable to the deceased individuals. In this study only healthy individuals are included so the results may not be applicable to persons having deformity or any congenital abnormality.

\section{Conflicts of Interests: None}

\section{REFERENCES}

[1]. Moorthy TN, Yin TY. Regression Analysis To Determine Stature From Fingerprints In Malaysian Chinese For Person Identification. J.Bio.Innov.2016; 5(3):411-418.

[2]. Suseelamma D, Gayathri P, Deepthi S, Chandra mohan M, Uday Kumar M, Amarnath. Study of Correlation between Stature and Length of Fingers. Sch. J. App. Med. Sci.2014; 2(2D):773-784.

[3]. Krishan K. Anthropometry in Forensic Medicine and Forensic Science-'Forensic Anthropometry'. Internet J. Forensic Sci.2006;2(1). Available from: http:// ispub.com/IJFS/2/1/10656.

[4]. https://en.wikipedia.org/wiki/Alphonse_Bertillon

[5]. Norgan N. Body-proportion differences. In: Ulijaszek $\mathrm{S}$, Johnston FE, Preece MA, editors. The Cambridge Encyclopedia of Human Growth and Development. New York: University Press NY; 1998. p. 378-379, 1998.

[6]. Lundy JK. The mathematical versus anatomical methods of stature estimate from long bones. Am J Forensic Med and Path. 1985; 6:73-76.

[7]. Sjøvold T. Stature estimation from the skeleton. In: Siegel J, Saukko P, Knupfer G, editors. Encyclopedia of Forensic Sciences. San Diego: Academic Press. 2000;p 276-284.

[8]. Lundy JK. A report on the use of Fully's method of stature estimate in military skeletal remains. J Forensic Sci. 1988; 33:534-553.

[9]. Raxter $\mathrm{MH}$, Auerbach BM, Ruff CB. Revision of the Fully technique for estimating statures. Am J Phys Anthropol. 2006;130:374-384.

[10]. Martin R. Lehrbuch der anthropologie. In: Bannister LH, Berry MM, Collins P, Dyson M, Deusek JE, Mark WJ, et al., editors. Gray's Anatomy - Anatomical Basis of Medicine and Surgery. 38th ed. London: Churchill Livingston; 1999.

[11]. Anupriya A, R Kalpana R. Estimating the Height of an Individual from the Length of Ulna in Tamil Nadu Population and its Clinical Significance. International Journal of Scientific Study. $2016 \mathrm{Apr}$ ;4(1):254-257. 
[12]. Mondal MK, Jana TK, Jana SG, Roy H. Height Prediction from Ulnar Length in Females: A Study in Burdwan District of West Bengal (Regression Analysis). Journal of Clinical and Diagnostic Research. 2012 Oct;6(8):1401-1404.

[13]. Lal CS, Lala JK. Estimation of stature from tibial and ulna lengths in North Bihar. J Med Assoc. 1972;58:120-121.
[14]. Ilayperuma I, Nanayakkara G, Palahepitiya N. A model for the estimation of personal stature from the length of forearm. Int J Morphol. 2010; 28:10811086.

[15]. Allbrook D. The estimation of stature in British and ulna bone lengths. J Forensic Med.1961;8:15-27.

How to cite this article:

Anuj Jain, Ashok Kumar. ESTIMATION OF STATURE OF INDIVIDUAL WITH THE HELP OF LENGTH OF ULNA. Int J Anat Res 2019;7(1.2):6192-6197. DOI: 10.16965/ijar.2018.440 